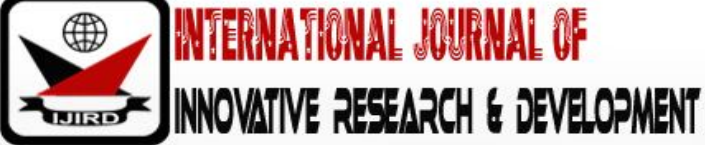

ISSN 2278 - 0211 (Online)

\section{Influence of Information Literacy Skills Requirement of Academic Library Staff for National Development}

Ashiver Elizabeth Annune
Librarian, Department of the University Library,
Federal University of Agriculture, Makurdi, Nigeria
Agoh Jessicah A
Deputy University Librarian, Department of the University Library,
Federal University of Agriculture, Makurdi, Nigeria
Ihongo Dominic A
Librarian, Department of the University Library,
Federal University of Agriculture, Makurdi, Nigeria

\begin{abstract}
:
Information literacy skills are indispensable tools for effective and efficient functioning of academic library staff in the information age. In information era, academic libraries have responded by providing instructions in information literacy that enable their staff acquire skills such as ability to locate, manage, critically evaluate and use information to solve problems, support teaching, learning, research as well as influence decision making. This paper discusses conceptualization, categories of information literacy, information literacy skills acquire by academic library staff, training methods used by academic library staff to acquire information literacy skills and influence of information literacy skills acquired by academic library staff on national development. The study also reveals that acquisition of information literacy skills by academic library staff would ensure free flow of knowledge, library and information services to users for national development.
\end{abstract}

Keywords: Literacy, information literacy, national development, information literacy skills, academic libraries

\section{Introduction}

Information Literacy is considered as the link pin and defensive mechanism for national development. It is a key factor in lifelong learning and the first step in achieving educational goal. In essence, it facilitates learning, acquisition of knowledge, skills, values, beliefs and creates cultural awareness. The concept of information literacy, emerged with the advent of information technologies in the early 1970s, has evolved over the years to become a viable tool for national development in the 21st century. Some scholars have opined that the development of information literacy should take place throughout the life of an individual most especially the during educational years. The implication of this is that, academic library staff require to acquire information literacy skills that will help them recognize when information and services are needed, method of communication, understanding the socio-economic and political implication of information for national development. Academic library staff is the entire group of paid employees responsible for the operation and management of library or library system in institutions of higher learning (Shidi, 2011). Academic library staff includes professional librarians. These groups of people ensure that users have access to information at the right time of need. The implication for academic libraries staff is to acquire current information literacy skills that would help them to identify and analyze information resources and services as well as determine when and where same is needed. Information sharing needs to demonstrate sensitivity to socio- economic and political implication for national development. Access to information is one of the dominant factors for national development. The need to determine what information we need and where to obtain it, how to select, evaluate and utilise it to advance individual and collective progress is of utmost importance for national development.

According to Kothari Commission quoted by Satbir (2014), national development isthe continuous rise in standard of living of masses,reduction of unemployment, equal opportunities for social, political and economic development, good and impartial administration, mutual understanding and sense of co-operation amongst masses. National development is the overall collection of social-economic, political and religious advancement of a nation. It is people oriented and its success is evaluated in terms of the impact it has on improving the lots of the citizens. The nation in which her citizens acquired information literacy experienced meaningful development. It is a train that drives citizens to a better understanding which in turn induces sound judgement and decision making. Information literacy is a key component in the national development as it contributes essentially to the ability of academic library staff to work confidently with information, information technology tools and to develop essential critical thinking skills. Information 
literacy primary goals are to get people thinking critically about the information they encounter and building in people the ability to use that information to create new knowledge. Hikwa (2007) advanced that, without information, national development plans remain idealistic and very much inclined towards failure. An informed nation is akin to national processes since it cannot be separated from each other. This entails that, information is needed in all human endeavours for effective development to take place in any nation. Lack of information literacy skills among academic library staff may prevent them from maximally contributing their quota to national development. This paper therefore, looked at conceptualization, categories of information literacy,information literacy skills acquire by academic library staff, training methods used by academic library staff to acquire information literacy skills and influence of information literacy skills acquire by academic library staff on national development.

\section{Conceptualization}

The phrase "information literacy" first appeared in print in 1974 report by Paul G. Zurkowski, written on behalf of the National Commission on Libraries and Information Science. He used this phrase to describe the "techniques and skills" known by the information literate" for utilizing the wide range of information tools as well as primary sources in moulding information solutions to their problems". However, it is impossible to come out with a single definition of information literacy as different authors, scholars and researchers have defined the concept in several distinct ways based on their perspectives. Before we discuss information, literacy let us first of all look at the word literacy.

Traditionally, literacy means the ability to read and write. The International Adult Literacy Survey (IALS) (2009) defines literacy in terms of proficiency levels of the use of information to function in society and in the economy. Literacy is defined as a particular capacity and mode of behaviour, the ability to understand and employ printed information in daily activities, at home, at work and in the community to achieve one's goals and to develop one's knowledge and potentials (OECD/ Statistics Canada, 2000). Five levels of literacy have been identified and defined as:

- Indicate persons with very poor skills: where the individual may not be able to understand the information in print format.

- Respondents can deal only with material that is simple, clearly laid out and in which the tasks involved are not too complex: It denotes a weak level of skills, but more hidden than Level 1. It identifies people who can read, but test poorly. They may have developed coping skills to manage everyday literacy demands, but their low level of proficiency makes it difficult for them to face novel demands such as learning new job skills.

- Considered a suitable minimum for coping with the demands of everyday life and work in a complex, advanced society. It denotes roughly the skill level required for successful secondary school completion and college entry. Like higher levels, it requires the ability to integrate several sources of information and solve more complex problems.

- Levels 4 and 5 describe respondents who demonstrate command of higher order information processing skills (OECD/ Statistics Canada, 2000, Virkus, 2003).

Doyle (2008) described an information literate person as one who recognises the need for information to be accurate and complete as a basis for intelligent decision making: formulate questions based on the needs, identify potential sources of information, access sources of information including computers and other technologies, evaluate information, organises information to integrate new information to the existing body of knowledge and practical application, use information in critical thinking and problem solving. A person is one person who acquires and effectively applies the essential knowledge and skills such as reading, writing and arithmetic towards personal and community activities for community development. An information literate individual should be able to access various sources of information independently and efficiently, interpret and make valued judgements.

\section{Information Literacy}

Information Literacy according to US National commission on Library and Information Science quoted by Naik and Padmini, (2014) encompasses knowledge of one's information concerns and needs, and the ability to identify, locate, evaluate, organize and effectively create, use and communicate, information to address issues or problems at hand. It is a prerequisite for participating effectively in the information society, and is part of the basic human right of lifelong learning" (Webb and Powis quoted by Naik and Padmini, 2014). Information for All Programme (IFAP, 2008) defined information literacy as the capacity of people to recognized their information needs, locate and evaluate the quality, store and retrieval information, make effective and ethical use of information and apply information to create and communicate knowledge. Information literacy enables people to express personal ideas, develop constructive arguments, refute the opinions of others, learn new things or simply identify the truth or factual evidence about a topic. The scope of information literacy includes computer literacy, information technology literacy, internet literacy, digital literacy, media literacy and more. The whole concept of information literacy is to move from text-based learning to practical-based learning.

Also, Shapiro and Heghes (1996) defined information literacy as, "new liberal art that extend from knowing how to use computers and access information to critical reflection on the nature of information itself. It is the combination of all the skills required for effective and maximum use of information. Information Literacy is the ability to gather, organize, filter and evaluate information to form valid opinion based on the results. The users who inculcate in themselves new and current methods obtain the quality of creating meaningful work. It is therefore very expedient that library staff possess the skills with which to serve these users and provide the needed information they desire. Webber \& Johnston (2002) defined information literacy as efficient and ethical information behaviour. They further stated that information literacy is the adoption of appropriate information behaviour to obtain, through whatever channel or medium, information well fitted to 
information needs, together with critical awareness of the importance of wise and ethical use of information in society. Boekhorst (2003) asserted that, all definitions and descriptions of information literacy presented over the years can be summarized in three concepts:

- The ICT concept: Information literacy refers to the competence to use ICT to retrieve and disseminate information.

- The information (re)sources concept: information literacy refers to the competence to find and use information independently or with the aid of intermediaries.

- The information process concept: information literacy refers to the process of recognizing information needs, retrieving, evaluating, using and dissemination of information to acquire or extend knowledge.

This concept includes both the ICT and the information resources concept and persons are considered as information systems that retrieve, evaluate, process and disseminate information to make decisions to survive, for self-actualisation and national development (Virkus, 2003).

\subsection{Categories of Information Literacy}

The information literacy has been recognised by librarians and information professionals as a collective term covering various types of literacy such as computer literacy, digital literacy, hyper literacy, information technology literacy, electronic literacy or electronic information literacy, interactive literacy, multiple literacy, network literacy, oral literacy, internet literacy, reading literacy, water literacy and visual literacy, library literacy, etc (Naik and Padmini 2014, Bawden, 2001, Virkus, 2003). Other categories include IT (Information Technology) literacy, cultural literacy, functional literacy, voter literacy, work-related literacy and lot more. Auduns on and Nordlie (2003) also highlight three main categories of information literacy as technical capabilities or what one might call computer literacy, intellectual capabilities related to traditional literacy and communicative competency that presupposes technical as well as intellectual capabilities and at the same time transcends them. The categories are further distinguished according to levels of competence, from basic competence to super user competence to in-depth competence and consider information literacy as the sum of different 'literacy' (Virkus, 2003). Literacy is basic skill requirement for successful personal and professional life style of an individual for national development.

\section{National Development}

National development refers to the ability of a country or countries to improve the social welfare of the people by way of providing social amenities like good education, infrastructure, medical care, social services, etc. Brooks quoted by Afolabi (2009) maintained that national development involves economic growth, modernization, equitable distribution of income and national resources and social economic transformation for improved living standards of people through the use of a country's human, natural and institutional resources. Ikpaahindi (2009) described national development as the transformation of the various (political and socio-economic) aspects of the life of the nation. He further stated its implication as a progression from a low undesirable state to a higher desirable one or vice-versa. National development is the holistic attempt to improve the lives of citizens by way of reducing poverty, improving on social amenities like schools, transportation, health care, electricity, etc. as well as encouraging them to meet their aspirations and goals that geared towards the progress of the nation. Satbir (2014) advanced that, when all the forces and factors endeavour to provide a unity in the integration of national actions and challenges which encourages the people to meet their aspirations and goals related to their personal and social benefits which willingly or unknowingly geared to the national progress is known as National Development.

\subsection{Information Literacy Skills Requirements of Academic Library Staff for National Development}

The amount and volumes of available information resources in the society today has brought us into the era of information Age. This calls for remarkable skills and competencies from academic library staff to function effectively. In the present information era, academic library staffs are required to acquire information literacy skills that enable them function effectively and efficiently for the success of academic institutions and national development. Skill is an ability and capacity acquired through deliberate, systematic and sustained effort to smoothly and adaptively carry out complex activities or job functions involving ideas (cognitive skills), things (technical skills) and people (interpersonal skills). It is a learned power of doing something competently, developing aptitudes or ability to demonstrate what one learned from training, experience and practice. Anttiroiko, Lintilä and Savolainen (2001) pointed out that, skills involve the ability to pragmatically apply, consciously or even unconsciously, our knowledge in practical settings. They further emphasized that, in this setting, 'skills' can be conceived as the technical aspects of competence, emphasizing the aspect of 'how to do'. With information literacy skills acquired by academic library staff, library operations become more effective and less stressful on daily basis. Information literacy is a set of skills that spills over into other areas of skills development, including IT and academic writing. Idiodi (2005) advanced that, information literacy skills acquisition is an aspect of information literacy and may be seen as the process of gaining the tools that assist development of information literacy in an individual. According to Bruce (2008) information literacy skills include the ability to find, evaluate, store and manage information; to re-use it to create new knowledge or solve problems; and to understand that information exists within social, ethical, cultural and legal contexts.

In addition, Peltier-Davis (2009) proposed fourteen-point checklist such as: have the capacity to learn constantly and quickly, have the propensity to take risks and work under pressure, be skilful at enabling and fostering change, have a sense of humour, become an advocate for the profession. Professional skills are those techniques that relate to the librarian's knowledge and ability to applying these knowledges in the areas of information resources, information access, 
technology and management. Academic libraries aim at providing its users with key, high-level generic skills like the capacity for lifelong critical, conceptual and reflective thinking and attributes such as creativity and originality. Generic skills refer to attitude and values that enable library staff to work efficiently and effectively, be good communicators, focus on continuing learning throughout their careers, demonstrate their value-added nature of contributions and thrive in the new world of education. The academic library service delivery without skills may render staff ineffective, therefore, acquisition of appropriate and adequate information literacy skills should become the basic needs of every library staff. Academic library staff that acquires skills of internet services, data-based creation, intranet, scanning techniques, MSOffice, networking, content and systems development, digitization, web-based services and virtual learning will enhance access to information resources for national development. Oketunji quoted by Okere (2005) identified skills requirement of academic library staff as skills to learn and use the ever-changing technologies; communication and interpersonal skills; ability to market library services and managerial skills. Managerial skills such as team building skills, financial management skills, change management skills, local and global thinking skills, planning and organisational skills, resource management skills, decision making skills, leadership skills, negotiation skills and time management skills e.tc acquisition will facilitate effective library operation.

Organization for Economic Cooperation and Development (OECD) quoted by Naik and Padmini, (2014) highlighted the skills of finding, interpreting information, the ability to seek and exchange information using databases and networks, access to other technology and possession of necessary technical skills are the requirement for library staff. Technical skills are professional skills that academic library staff considered to be the most important skills that entailed the ability to select, analysis, acquire, catalogue and classify information resources for storage and retrieval for national development. Ugah (2012) maintained that, cataloguing is a skill central to library profession and forms the foundation upon which other skills needed in the academic library rest such as online database search skills, use of open access catalogue (OPAC), search strategies to locate and access relevant information which include keyword search and the use of Boolean logic operators (which are AND, OR, NOT), ICT tools like as computers, internet and power point presentation software, creating web pages). Based on this, academic library staff requires to acquire ICT skills in addition to their core traditional and information service skills for national development. Information literacy helps library staff to acquire skills of citation and referencing. Mngutyo, Ngushin and Obande (2017) advanced that library staff need information tool literacy skills like use of library, study skills, computer literacy skills, ICT literacy skills, data bases skills and search skills, evaluative skills, information management skills and information utilization skills. Other skills include information documentation, dissemination, acquisition, processing, storage, conservation and preservation, marketing and entrepreneurship skills are relevant to academic library staff for national development. Snoj and Petermenec (2001) maintained that, marketing skill is beneficial to libraries because an effective marketing programme can help the library create competitive advantage through development of new services or changes to existing ones to satisfy their users better, improvement of their organisational status and image to different stakeholders and thereby improving their performance in general. Possession of marketing skills will substantially contribute to better and aggressive performance in library and information service rendered in the academic institutions. Kavulya (2004) pointed out the key components staff needed to be developed by academic library staff as understanding, applying the theoretical and practical concepts of non-marketing to the analysis of library and information organisations, effective management approaches to marketing survey design and public relation activities that reflect marketing research. In addition, communication skill is essential in library operations where library staff are required to interact with users to articulate their information needs clearly. Katz (2002) stated that, conservational skill is the ability to talk to all types of people and to find out what they need. The attributes of acquiring communication and lifelong learning skills and developing efficient research and information retrieval skills are fundamental academic libraries mission to their staff.

\subsection{Training Methods for Which Academic Library Staff Used in Acquiring Information Literacy Skills}

Acquisition of information literacy skills is done through different methods such as training, retaining, practices and experiences. Cole (2002) pointed out that, any learning activity which is directed towards the acquisition of specific knowledge and skills the purpose of an occupation or task is referred to as training. He further categorises the staff training as off job and on job methods. Off job training includes lecture/ talks, programme instruction, classroom instruction, case-study analysis and simulation. On-job training includes job instruction, learning from experience workmate, coaching/ counselling, delegation, secondments and special projects. Academic library staff are trained to acquire information literacy skills that will facilitate effective service delivery. Ugwu and Ekere (2010) emphasized that, training is the process where library staff learn new skills or techniques that will transform them from the state of not being efficient to being able to do the job effectively or completely. They further advanced that, through training employees learn their jobs fast, improve their work performance and keep up to date in their field. Information literacy skills training could be obtained either through constant practice or level of education. Academic library staff usually acquires their skills via enrolling in library and information science courses, understudying other staff and as a result of accumulated experiences. Chevvillotte (2010) stated that, library should be a teaching place of information literacy as can be seen from other literacies to compliment the efforts of educational institutions. The author further maintained that, it is a new role that require most librarians to develop new competencies and professional skills just like online environment that have had impact on the responsibilities of the librarian who has increasingly become a teaching librarian. Academic library staff acquires information literacy skill mostly through attending workshops/ seminars, conference, self-taught, assistance from other colleagues, trial and error, on the job training, attending IT programmes and through organisation of information literacy skills programmes. The University of Auckland Academic Plan 2005-2007 (2004) Stated that, it is the duty of library management to constantly organise information literacy skills programme in order to develop information 
literate users. Academic library management in conjunction with their parent institutions can organize information literacy in-house training programme for their staff to enhance their skills.

\subsection{Impact of Information Literacy Skills Acquisition of Academic Library Staff on National Development}

Information literacy skills of academic library staff have uniquely influenced national development directly and indirectly in so many ways. With information literacy skills acquisition, academic library staff can provide relevant, updated and adequate information on all forms of human endeavours such as food security, health, democracy, population, education, family planning, youth empowerment, gender equality, environment etc. (Achitabwino, 2007). Significantly, academic library staff in the $21^{\text {st }}$ century are charged with the responsibility of inculcating information literacy skills that will help users apply information in every sphere of human endeavours for national development. Access to information is a sure means of contributing positively to national development. Information literacy may help library staff to be equipped with the necessary skills as responsible informed citizens who can participate fully in societal activities thereby contributing meaningfully to national development. In essence, information literacy empowers library staff to participate in democratic processes, enables the progress of research and gives our students skills that help them succeed in their academic pursuit. Black and Leysen quoted by Ogah (2012) stated that, research skills are beneficial to the practices of librarianship and research component can strengthen several other areas of library operations such as reference, cataloguing and collection development. Academic libraries are no longer seen as only knowledge repositories but they serve as catalyst for national development. Libraries open up minds, inspire people to see visions because the mind is the centre point where progress originates and are responsible for feeding the mind of users with information (Abdulrahman, 2017).

Information literacy skills acquired by academic library staff enable them to provide solutions to the problems affecting the productivity of library staff, marketing of library resources and services, provide motivation to the work force and ensure sustainable patronage by library users Terna, Kuku and Uganneya (2017). Marketing is beneficial to libraries because an effective marketing programme can help the library create competitive advantage through development of new services or changes to the existing one to satisfy their users. This may improve their organizational status and image to different stakeholders, thereby improving their performance in general. Possession of marketing skills will contribute to better performances of library staff and as well draw attention of users to the existence of library products and information services. Katz (2002) emphasized that, effectiveness of the academic library staff in this all-important area of library operation will promote library use resulting to high academic performance which could translate to economic productivity. The key competences that staff needs to develop include, understanding, applying the theoretical and practical concepts of non-profit marketing, to analysis of library and information organisations, effective measurement approaches to marketing survey design and public relation activities that reflect marketing (Kavulya, 2004). As a result of information literacy skills acquired by academic library staff may help facilitate accessibility of information resources, make users more rational in their thinking as well as develop reading skills in them.

It is expected that literature searches for the purpose of disclosing the knowledge gap in a field of study should be systematically constructed. Besides field knowledge, such construction requires in-depth information literacy skills. Researchers have acknowledged that some academic library staff are equipped to help with this and many researchers request the support of these staff in this phase of the process. Some academic library staff are deeply involved in training students in the use of the resources available, how to find and evaluate information and some also cover issues of ethics, particularly relating to copyright, referencing and plagiarism. Those who are information literate can analyze and interpret information and this ability enables them to respond effectively and creatively to problems. Therefore, it can be said that information literacy contributes towards personal empowerment and freedom to learn as well as study independently. When library staff knows how to find and apply information, they can teach themselves as well as users what they need to learn which essentially contributes to national development. The ability to use information technologies effectively to find and manage information, critically evaluate and ethically apply information resources to solve problems are some of the hallmarks of information literate library staff. Information literate library staff usually has the spirit of inquiry and perseverance to find out what is necessary to get the job done. Academic library staff with information literate skills may have strong analytical, critical thinking and problem-solving ability, can be expected to be adaptable, capable and valuable employee, with much to contribute for national development. Information literate programme equips users with the 21st century research skills. One of the academic libraries missions is to develop information literacy skills and knowledge throughout their parent institutions' community. This is implemented through supporting users with information materials and aiding researchers in contributing their quota to national development.

Above all information literacy is a basic human right in the digital world and promotes social inclusion of all nations (Garner, 2005). Library staff are provided with skills to effectively and efficiently retrieve and use the information available from the large pool of resources. The process of information literacy requires not only learning of skills, but also a new way of thinking, in order to derive meaning from learning. The use of Technological tools for storage and sharing of information has increased the availability of data tremendously. Much of this information is available through telecommunications. Information literacy in telecommunication is achieved when learners know when to use online resources, how to access information, how to evaluate the accuracy and pertinence for each need and use information to communicate effectively. If learners learn these information literacy skills then they have the lifelong learning skills. Information literacy skilled staff knows how to use information for work and in everyday life experiences. They identify the most useful information when making decisions, when voting or to participate in community life. They are able to evaluate newscasts, advertisements and political campaign speeches. Increasing attention to information literacy in recent years is partly the result of information overload, especially related to the growth of digital information which has caused 
a new alignment called "information fatigue syndrome" and partly because of new focus on library staff and information professionals.

\section{Conclusion}

Information literacy skills is a mandatory virtue for every academic library staff in the $21^{\text {st }}$ century, hence, it serves as impetus for effective collection and provision of access to adequate, relevant and timely information for national development. The development of the nation partly hinges on the information literacy skills acquired by academic library staff. They ability to identify information needs, where to access, explore and enhanced utilization of information among users is paramount to better their lives and for nation development at large.

\section{References}

i. Abdulrahman, A.B. (2017). Information literacy for sustainable development in Nigeria.Paper presented at the 37th conference/ AGM of Nigerian Library Association (NLA)Benue state Chapter, held at Benue state library board Makurdi, July, 27th $-30^{\text {th }}$.

ii. Achitabwino, P. (2007). Libraries and national development. Retrieved fromhttp:/ / pachitabwino.blogstop.com/ 2007/ librarie-and -national-development.hml. On22/ 12/ 2017.

iii. Afolabi, o.A. (2009). Keynote address presented at the opening ceremony of the $2^{\text {nd }}$ heads oflibrarians National workshop organized by Nigerian Library Association (NLA) incollaboration with the center for leveraging information for production, Kaduna state university from $13^{\text {th }}-15^{\text {th }}$ October.

iv. Anttiroiko, A.V., Lintilä, L. \& Savolainen, R. (2001). Information society competenciesof managers: conceptual considerations, In: E. Pantzar, R. Savolainen \& P. Tynjälä, eds. Insearch for a human centredinformation society. (p.2757).Tampere:Tampere University Press.

v. Audunson, R. \& Nordlie, R. (2003). Information literacy: the case or non case of Norway? Library Review, 52(7), 319325.

vi. Bawden, D. (2001). Information and digital literacies: a review of concepts. Journal of Documentation, 57(2): 218259.

vii. Boekhorst, A. K. (2003). Becoming information literate in the Netherlands. Library Review, 52 (7), 298-309.

viii. Bruce, C. (2003). Seven faces of information literacy: Towards inviting students into new experiences. Retrieved from http:/ / kennison.name/ file/ zopestore/ uploads/ libraries/ bruce7-faces.pdf. On 18/ 1/ 2017.

ix. Chevillotte, S. (2010). Information literacy. In Marcia, J. B. \& Mary, N.M. (eds).Encyclopaedia of library and information science, 3: 2421-2426.

x. Cole, G.A. (2002). Personnel and human resource management. London: education low price text. p.123-128.

xi. Doyle, C. S. (2001). Information Literacy in an Information Society: A Concept for the Information Age. Syracuse, NY: ERIC monograph.

xii. Garner, SD.(2005). High-Level Colloquium on Information Literacy and Lifelong Learning. Egypt: Bibliotheca Alexandrina, Alexandria, UNESCO. Retrieved fromhttp://w3.ifla.org/files/ assets/informationliteracy/ publications/ high-level-colloquium20/10/2017.

xiii. Idiodi, E.A. (2005). Approaches to information literacy acquisition in Nigeria. Library Review 4:223-230.

xiv. Ikpaahindi, L.A. (2009). Issues of library development in Nigeria. Paper presented at the $2^{\text {nd }}$ heads of librarians National workshop organized by Nigerian Library Association (NLA) in collaboration with the center for leveraging information for production, Kaduna state university from $13^{\text {th }}-15^{\text {th }}$ October.

xv. Information for All Programme (IFAP, 2008). Information for all programme: Strategic plan 2008-2013. Discussion draft (17). Retrieved from http:/ / porter.unesco.org/ ci/ en/ files. On21/ 11/ 2017.

xvi. Karz, W.A. (2002). Introduction to reference work: Basic information services. New York:McGraw-Hill.

xvii. Kavulya, J.M. (2004). Marketing of library services: a study of selected university libraries in

xviii. Kenya. Library Management, 25 (3): 118-126.Naik, M.M. \& Padmini, I. (2014). Importance of information literacy. International Journal of Digital Library Services, 4 (3): 92-99.

xix. Ngutyo, J., Ngushin, R. T.\& Obande (2017). Information literacy requirement of special library staff for national development in Nigeria. Paper presented at the 37thconference/ AGM of Nigerian Library Association (NLA) Benue state Chapter, held atBenue state library board Makurdi, July, 27th -30th.

xx. OECD and Statistics Canada (2000). Literacy in the information age: final report of the international adult literacy survey. Paris: OECD and Statistics Canada.

xxi. Peltier-Davis, C. (2009). Web 2.0, Library user 2.0, and librarian 2.0: Innovative services for sustain able libraries. Computers in libraries, 29(10):16-21.

xxii. Quadri, G.O. (2016). Impact of ICT skills on the use of e-resources by information professionals: a review of related literature. Library philosophy and practice. Retrieved from http://questia.com/library/journal/lgl310257481/impact-of-ict--skills-on-the-use e- resources-. On 14/11/2017. Satbir, B. (2014). Education and development. Retrieved from bed notes./ blogspot.com/ 2014/ 02/ national development.html. On 2/ 11/ 2017.

xxiii. Shapiro, J. J. \& Hughes, S. K. (1996). Information literacy as a liberal art: enlightenment proposals for a new curriculum. EDUCOM Review, 31(2): 31-35. Retrieved from http:/ / www.educause.edu.

xxiv. Shidi, H. (2011). Information and communication (ICT) facilities and skills development of library staff in academic institutions in Benue State. MLS thesis submitted to the Department of library and information science, University of Nigeria Nsukka. 
xxv. Snoj, B. \& Petermanec, Z. (2001). Let users judge the quality of faculty library services. New Library World, 102 (1168): 314-324.

xxvi. Terna, R. \& Kuku, D. (2017). Information literacy skills requirement of academic library staff for national development. Paper presented at the 37th conference/ AGM of Nigerian Library Association (NLA) Benue state Chapter, held at Benue state library board Makurdi, July, 27th-30th.

xxvii. Ugah, A.D. (2012). Making successful career in librarian: the issue at stake. Personnel issues in the 21st century Librarianship, 2 (1\&2): 50-57.

xxviii. Ugwu, C. I. \& Ekere, J. N. (2010). Training needs of librarians for digital library projects in University libraries in Nigeria: A case study. In scholarly communication and information: mentoring, mastering \& and modernization. Nsukka: Nnamdi Azikiwe library. P. 453- 457.

xxix. Webber S. \& Johnston, B. (2002). Assessment for information literacy. Paper presented at the International conference on IT and information literacy. Glasgow: Scotland 20th- 22nd March. 